\title{
IMPACT ANALYSIS ON CORPORATE SOCIAL RESPONSIBILITY TOWARDS JOB PURSUIT INTENTION WITH SOCIO-ENVIRONMENTAL CONSCIOUSNESS AS A MODERATING VARIABLE: CASE STUDY OF UNDERGRADUATE STUDENTS AT UNIVERSITAS INDONESIA
}

\author{
Wulan Prihatiningsih, Muhammad Irfan Syaebani, Monica Devina \\ Department of Management, Faculty of Economics and Business, Universitas Indonesia, Kampus Baru UI \\ Depok \\ wulan.prihatiningsih@ui.ac.id, muhammad.irfan11@ui.ac.id,monica.devina@ui.ac.id
}

\begin{abstract}
Corporate Social Responsibility (CSR) is a company's responsibility to embrace positive impact to the society where it operates. On the other side, CSR is also a tool to balance the interests of the company and the society who is affected by the company's business activity. Therefore, besides fulfilling an obligation, CSR activity could be utilized as one of strategies to reach the company's goals including a strategy to increase job pursuit intention of job seekers, thus it enables company to pool as many prospective talents as possible. This quantitative research aims to examine the impact of the four dimensions of CSR economic citizenship, legal citizenship, ethical citizenship, and philanthropic citizenship - on job pursuit intention which is moderated by socio-environmental consciousness at a tobacco company which perceived as a generous company in carrying out its CSR activities. This research involved 203 undergraduate students majoring in accounting, management, and economics, class of 2012 at Universitas Indonesia. The data were collected using questionnaires and processed using the SPSS 20.0 software. The result shows that individual job pursuit intention considers a tobacco company as a prospective workplace which is significantly influenced by four dimensions of CSR, but the socio-environmental consciousness does not moderate the effect of CSR dimensions on job pursuit intention.
\end{abstract}

Keywords: CSR, economic citizenship, legal citizenship, ethical citizenship, Philanthropic citizenship, job pursuit intention

\begin{abstract}
Abstrak: CSR adalah kewajiban perusahaan yang bertujuan memberikan dampak positif bagi masyarakat di lokasi tempat perusahaan beroperasi. Di sisi lain, CSR juga merupakan alat untuk menyeimbangkan kepentingan perusahaan dengan kepentingan masyarakat yang terdampak aktivitas bisnis perusahaan. Oleh sebab itu, selain pemenuhan kewajiban CSR juga bisa bermanfaat sebagai salah satu strategi untuk mencapai tujuan perusahaan termasuk strategi untuk meningkatkat job pursuit intention. Strategi ini bermanfaat untuk mengumpulkan sebanyak mungkin kandidat pekerja yang berkualitas bagi perusahaan. Penelitian ini adalah penelitian kuantitatif yang mencoba menganalisis dampak dari empat dimensi CSR ekonomi, legal, etis, dan filantropis - terhadap job pursuit intention yang dimoderasi oleh kesadaran sosiallingkungan pada perusahaan rokok yang dianggap paling getol melakukan CSR. Penelitian ini melibatkan 203 mahasiswa sarjana jurusan manajemen, akuntansi, dan ilmu ekonomi di Fakultas Ekonomi dan Bisnis Universitas Indonesia. Data dikumpulkan melalui kuesioner dan diolah dengan perangkat lunak SPSS 20.0. Hasil penelitian menunjukkan bahwa job pursuit intention pada perusahaan rokok dipengaruhi secara positif oleh aktivitas CSR perusahaan tetapi variabel kesadaran sosial-lingkungan tidak terbukti memoderasi efek CSR terhadap job pursuit intention.
\end{abstract}

Kata kunci: CSR, dampak ekonomi, dampak legal, dampak etis, filantropis, intensi melamar kerja

\section{INTRODUCTION}

Indonesia is one of the biggest world tobacco producers after Argentina. In 2007, Indonesia accounted to $2.67 \%$ world tobacco production. In ASEAN, Indonesia tobacco contributed to $57 \%$ of total ASEAN production in 2012 ("Kajian Singkat Potensi Dampak Ekonomi Industri Rokok di Indonesia," n.d.). Tobacco industry is contributed to 
Indonesia economy through job creation and government income from cigarette taxes. The largest tobacco industry in Indonesia lies in four cities; Kediri, Kudus, Malang, and Surabaya. Ernst and Young analyzed that tobacco industry employs nearly 5.98 million workers and contributes to 154 trillion rupiahs of government income in 2014.

Indonesia placed as the third biggest smoker countries in the world after China and India. In ASEAN, Indonesia ranked the first biggest smoker country. According to Basic Health Research in 2013, there are 5 provinces in Indonesia with the highest prevalence of smokers; Lampung, NTB, Kalimantan Barat, Bengkulu, and Jambi ("Perilaku Merokok Masyarakat Indonesia," n.d.). The increasing number of smokers positively related with the number of tobacco-cause death. Research of Ministry of Health explained in 2012 tobaccocause death reached 190,260 cases or $12.7 \%$ of total mortality. Increasing trend of smokers impacted in two folds; positive and negative. Tobacco industry could enhance economics growth but on the other hands it causes health problems which cost huge fortunes. Although positive effect is given by tobacco industry through job creation and taxes, it does not make Tobbaco Companies widely accepted by public. Majority of public still considered tobacco is more damaging compare to benefit it gives. Cigarette is one of cancer causes thus it is rejected by many parties such as academics community. Tobacco related products were prohibited in academic institutions. The sale of cigarette strictly not allowed in academic places and civitas academics are also not permitted to ask for sponsorship for any academic-related events from Tobacco Companies.

Rejection from many institutions indicated that public awareness of health problem caused by cigarette is high. In this research, the awareness of public about tobacco issues defined through socio-environmental consciousness variable. Socio-environmental consciousness is concern of individu which reflects individual recognition, individual judgement, and individual attitude to social and environmental issues (Chang \& Chen 2012; Kirkham et al 2009; Pedersen 2006 in Tsai, Joe, Lin \& Wang, 2014).
High awareness of public to bad impacts of tobacco related products made cigarette companies have limited space to exercise their business activities. The existence of tobacco industry is legalized by law, but it does not mean that society would accept it morally. As a strategy to build good corporate image, thus make cigarette companies accepted by the public, the company could carry out corporate social responsibility (CSR) activities. CSR activities may raise company's social performance. Fritz (2009 in Mandina, Maravire, and Masere, 2014) argued that nowadays companies engaged in CSR activities to leverage their image. Bennet et.al (2006 in Mandina, Maravire, and Masere, 2014) explained the main advantages of carrying out CSR activities are to create positive image, attract media attention, change behavior, and help maintaining relationship between company and government. CSR activities also gave positive image to the shareholders. Mandina, Maravire, and Masere (2014) strengthened the statement that CSR activities impacted to company positively. According to Adetunji and Ogbonna (2013), CSR activities can raise capabilities of company to attract and retain human talent. Adetunji and Ogbonna (2013) also revealed positive relationship between CRS activities and reputation or company's image which in the end will result in higher level of company attractiveness for job seekers. Development of CSR concept in 1970-1980 formulated 4 dimensions of CSR activities: economic citizenship, legal citizenship, ethical citizenship, dan philanthropic citizenship.

Turban and Greening (1997) stated job seekers tend to prioritize job from company which perceived as socially responsible rather than from company perceived as socially irresponsible. Company with good social performance could attract more job applicants thus allow company to pool as many as possible qualified prospective candidates. It will create competitive advantage for the company in the long run (Williamson et al, 2003 in Tsai, Joe, Lin and Wang, 2014). Company could utilize CSR activities as a tool to increase applicants' intention to apply for job or in this research is called as job pursuit intention. According to this phenomenon, this research tries to examine relationship between CSR activities 
of a tobacco company in Indonesia with job pursuit intention to apply for job in Tobacco Company. Final year students of Faculty of Economics and Business Universitas Indonesia are the subject for the research. This research also involved socio-environmental consciousness as moderating variable which will strengthen or weaken relationship between CSR activities and job pursuit intention.

\section{LITERATURE REVIEW}

\section{Corporate Social Responsibility}

CSR is a company obligation to improve local public welfare where it operates (Davis \& Blomstorm, 1975 in Chang \& Chen, 2012). Bowen (1953) in Madina, Maravire, and Masere, (2014) defined CSR as company's duty to formulate policies, decisions, and actions in accordance with purposes and values which public believed in place where company operates its business activities. Above definition emphized that CSR is company's responsibility to give positive externalities to local public to balance company's interest with public interest who directly affected by company business activities. In 1970-1980 concept of CSR is enriched by formulation dimension of CSR activities into 4 dimension; economic responsibility, legal responsibility, ethical responsibility, dan discretionary responsibility or philanthropic citizenship.

This research applies 4 dimensions of CSR activities as indicator to measure company action concerning social duties. Company is economics basis unit which in its business activities produced goods and services, thus its main role is to create economic benefits to people. It is called as economic citizenship. Company is also hoped to obey rules and regulations required by government. In running business action, company must not violate law and it is called as legal citizenship. In business, following the law considered as not enough. Company should act above required by law because law is perceived as minimum standard of ethics. If company perceived by public acts more than required by law, it considered as ethical citizenship. The last dimension is discretionary responsibility or philanthropic citizenship. Company existence is expected to produce extra benefits to people surround thus it ensure that company is not only focus in profit seeking but also concern to social welfare. If the company followed these 4 dimensions of action in conducting its business activities, it is considered as already fulfilled corporate social responsibilities activities. Vice versa, if company does not adhere these 4 dimensions in conducting business it is perceived as company which socially irresponsible.

Turban and Greening (1997) explained that CSR describes values and norms of a company which can affect on how job seekers conceive working environment and condition in targeted company. Finally, it will impact level of attractiveness of a company in the perspective of job seekers. Adetunji and Ogbonna (2013) found out that CSR is positively related with company's attractiveness and image which at last will determine the successfulness of company to win war of talents. Through CSR, company could increase job seekers willingness to apply or simply called as job pursuit intention.

Even though it is widely believed that CSR gave positive impact in raising job pursuit intention level, Olsen (2006) warned that it could be no effect at all. He argued that company conducting CSR activities sometimes perceived as dishonest entity which try to hide its greedy behavior in seeking profit. CSR activities is only a mask to cover these bad actions, if this happen CSR activities most likely will give insignificant effect to job pursuit intention. This research tries to reveal is there any relationship between CSR activities and job pursuit intention in tobacco company. Tobacco Company is one of the most generous organization in creating events to improve social welfare and its business action is limited with many regulations to follow, but on the other hands, products which created by tobacco company are seemed as harmful because it cause many health related problems.

\section{Job Pursuit Intention}

Job pursuit intention defined as willingness of a person to seek job in certain company. High level of job pursuit intention possed by job seeker to a certain company will give the company more opportunities to pool as many qualified applicants as 
possible (Tsai, Lin, Ma, and Wang 2015). Aiman-Smith, Bauer, and Cable (2001) formulated job pursuit intention as an action of job seeker to actively seek information of a prospective company, make relationship with prospective company, and try to get chance to be interviewed. It means job pursuit intention is a variable to measure likelihood of job seeker to apply for a job in certain company. According to Rynes (1991 in Chapman, 2005) job pursuit intention is an output on how high determination level of job seeker to apply for job, follow recruitment process, and to accept job offer which indicated a person to join a prospective company without commitment to job choice (Chapman, 2005).

Based on Aiman-Smith, Bauer, and Cable (2001), they stated 2 predictors of job pursuit intention; there are job factor consists of compensation system and promotion and image factor consist of lay-off policies and ecological rating. Image factor could enhance job seeker intention to apply because good image transmited good message to people (Chatman, 1989 \& Rynes, 1991 in AimanSmith, Bauer, \& Cable, 2001). Strand, Levine, and Montgomery (1981 in Aiman-Smith and Bauer, 1996) explained 4 jobs attribute which becomes predictor of company's attractiveness; there are self development, remuneration system, environmental responsibility, and justice level of company in treating its employees.

Other researches of job pursuit intention revealed that predictor of people to apply for certain job in certain company is based on company's compensation, promotion opportunities, location, benefit, autonomy, flexibility, and type of job (Cable and Judge, 1994; Rynes, 1991; Rynes et.al., 1983; Schwab, Rynes, \& Aldag, 1987 in AimanSmith, Bauer, and Cable, 2001). Syaebani, Anoviar, Pusparini, and Rachmawati (2015), in their research found out 3 predictors of $j o b$ pursuit intention and one of them is employer familiarity. When a person is familiar with a company and perceived it as a good one, the likelihood of a person to join is bigger. Company may improve its familiarity by carrying out CSR activities. Besides creating positive image, CSR also can make company more familiar. It will make people aware of it and at last make company as one of prospective place to work chosen by job seeker.

\section{Socio-Environmental Consciousness}

Socio-environmental consciousness is a concern which reflects people recognition, people judgement, and people attitude and behavior on social and environmental issues (Chang \& Chen, 2012; Kirkham et.al. 2009; Pedersen, 2006 in Tsai, Joe, Lin, and Wang, 2014). Socio-environmental consciousness is a merge from 2 variables: socio consciousness which means awareness of social environment and environmental consciousness which means awareness of nature environment.

Social consciousness explained careness among individuals and concern not only for him self/her self but also concern for surrounding environment where he/she lives. This research emphasizes socio-environmental consciousness more as behavior thus socioenvironmental consciousness refers to every action which showed people concern to social and natural environment surround them.

A person perceived as having high level of socio-environmental consciousness when he/she not only showing his/her attitudes but also already showed real action which care to his/her social and natural environment. This research tries to measure socio-environmental consciousness as behavior or at least as intention to behave as moderating variable which may strengthen or weaken relationship between independent and dependent variables.

\section{Relationship CSR and Job Pursuit Intention moderated by Socio-Environmental}

\section{Consciousness}

Research conducted by Yuan-Hui Tsai, Sheng-Wuu Joe, Chieh-Peng Lin, and RongTsu Wang in 2014 found out that there is relationship between CSR and job pursuit intention moderated by individual awareness toward social and natural environment. The research explained that individual awareness toward social and natural environment (or in this research termed as socio-environmental consciousness) positively affected relationship between CSR and job pursuit intention especially ethical citizenship and philanthropic citizenship dimensions (Tsai, Joe, Lin \& Wang et.al, 2014). In this research, we adopt previous preposition concerning relationship between CSR and job pursuit intention and 
apply it to Tobacco Company as study case for contextualization. It is because social issue about exsistence of tobacco industry still debatable in public. As one of effort to be accepted, many Tobacco Companies tried to implement CSR activities and ensure that their business conducts follow the regulation thus avoid them to create negative image which could harm their reputation in controversial environment that already surrounded them.

According to Aiman-Smith, Bauer, and Cable (2001) one of important factors in creating job pursuit intention is image factor. This statement has already been proved by Adetunji and Ogbonna in 2013. Good image is resulted from good CSR activities since CSR strongly related to company's reputation. Job pursuit intention becomes important because to be success, company needs to hire qualified employees since people are the key factor in every organization. If the company cannot attract qualified people to work for them, it will result in loss of competitive advantage which is needed to enhance company's performance.

In this research, socio-environmental consciousness is treated as moderating variable. Many references already mentioned that person who has high level socioenvironmental consciousness tend to avoid to work in company which perceived as bad in economic citizenship dimension, because people will likely to conceive economic citizenship as important factor that must be adhered by company to help eliminate social problems such as education, poverty, and unemployment (Perez et.al., 2012; Wilson, 2000 in Tsai, Joe, Lin and Wang, 2014). If company failed to meet this economic citizenship, it will perceive as social irresponsible organization. An individu with high level of socio-environment consciousness usually choose to work in legal organization. Legal organization defined as companies which in their operations follow the rules and regulations and have comprehensive ethical code of conduct to minimize illegal and unethical business behavior. Socioenvironment consciousness strengthens relationship between CSR and job pursuit intention because individu with high level of awareness tend to consider a company which concern to social and environmental welfare as place to work.

\section{RESEARCH METHODS}

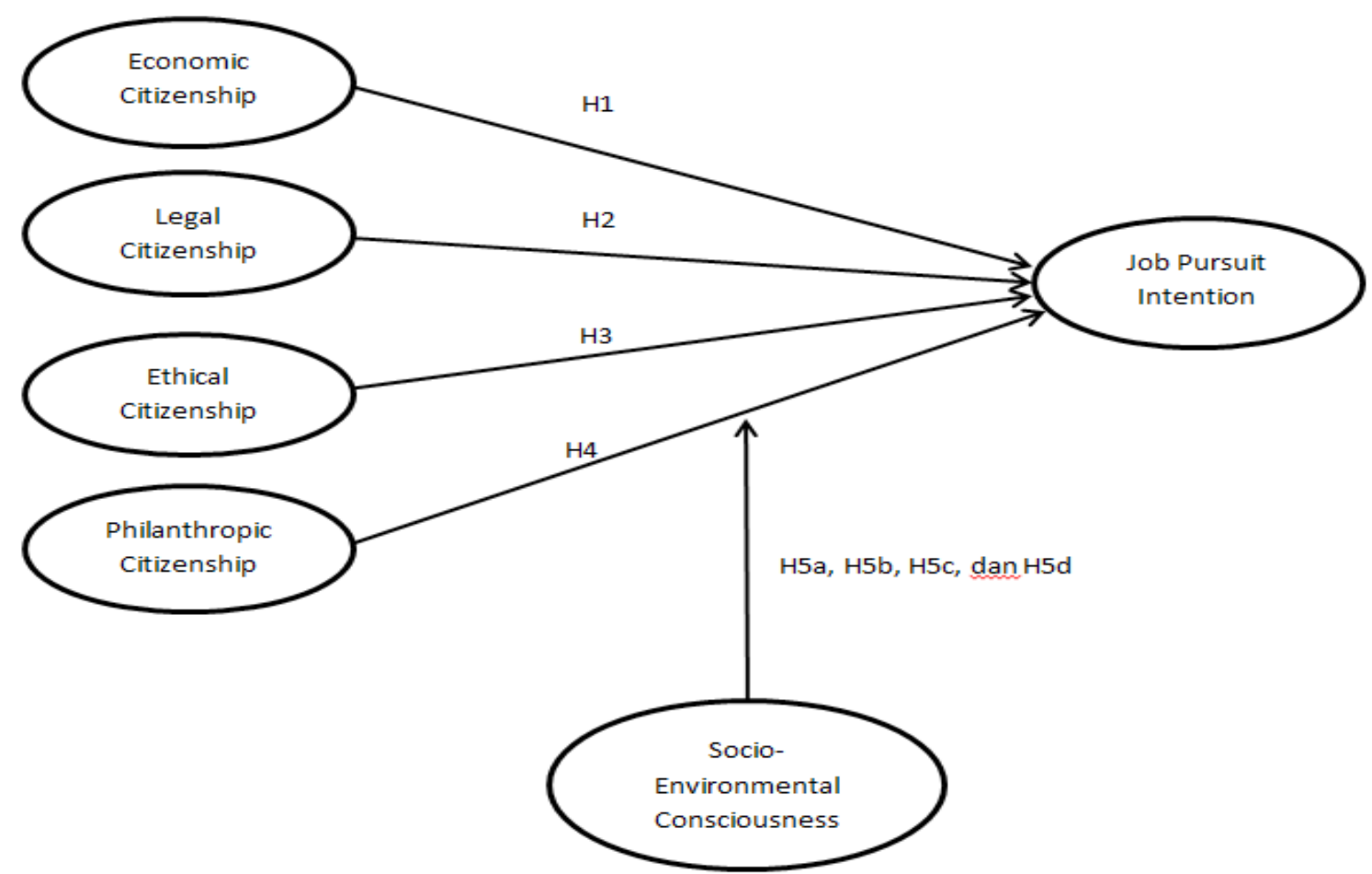

Figure 1: Research Model 
For company, implementing CSR activities is no longer a legal obligation to obey or just charity action, but it is a tool to shape company's image. Organization wants to get competent employees by creating the best workplace image which spreads to prospective employees. This image can be shaped through CSR. Previous literatures already mentioned that good CSR will improve job pursuit intention among prospective job seekers to apply job in the company and this relationship is moderated by socioenvironmental consciousness variable which could strengthen or weaken the relathionship between those 2 variables. Thus, research model in this research is as follow:

Economic responsibility or economic citizenship defined as company's duty to provide goods and services needed by public which are sold to gain profit. Zahra and LaTour (1987 in Lin, Lyau, Tsai, Chen, dan Chiu, 2010) added that in economic responsibility company must give useful values and benefit to its employees and its stakeholder. One of economic citizenship acts is giving fair compensation for the workers. Research conducted by Aiman-Smith, Bauer, and Cable (2001) revealed that salary is the main motive for people to apply a job in a certain company, thus the hypothesis 1 is: economic citizenship positively related to job pursuit intention.

In running business activities to reach company's objectives, it must be ensured that company obeys the rules and regulations in place where it operates. Job seekers will likely to apply to a company which perceived as comply with legal regulation rather than to a company perceived as contravene to legal law (Belt \& Paolillo, 1982; Gatewood, 1993; Lefkowitz, 2006 in Tsai, Joe, Lin, \& Wang, 2014). Therefore the hypothesis 2 is: legal citizenship positively related to job pursuit intention.

Carroll (1979 in Solihin, 2008) defined ethical citizenship as obligation for a company to behave in ethical way in every business actions. Geva (2008 in Tsai, Joe, Lin, and Wang, 2014) explained ethical conducts will ensure the protection of moral right of every stakeholder. The likelihood of applicants to apply to a certain company will be high if company is considered ethical in treating its stakeholder (Schwepker, 2001 in Tsai, Joe,
Lin, \& Wang, 2014). It leads to the hypothesis 3 which is: ethical citizenship positively related to job pursuit intention.

Maignan and Ferrell (2000 in Lin, Lyau, Tsai, Chen, and Chiu, 2010) defined philanthropic citizenship as duty of a company to involve in social activities that may be unregulated and unrequired in legal formal law. Research of Chieh-Peng Lin, Yuan-Hui Tsai, Sheng-Wuu Joe, and Chou-Kang Chiu in 2012 revealed that company with high level awareness to social welfare tends to have positive image and reputation. Finally, this good image will increase intention of job seekers to apply. Thus the hypothesis 4 is: philanthropic citizenship positively related to job pursuit intention.

This research applies socio-environmental consciousness as moderating varable. Socioenvironmental consciousness defined as concern which reflects individual recognition, individual judgement, and behavior toward social and environmental issues (Chang \& Chen 2012; Kirkham et al 2009; Pedersen 2006 in Tsai, Joe, Lin \& Wang, 2014). Literatures said that individual with high level of socio-environmental consciousness tend to avert to work in organization which considered as poor in economic citizenship dimension. It leads to the hypothesis $5 \mathrm{a}, \mathrm{b}$, $\mathrm{c}$, and d: Socio-environmental consciousness moderates relationship between economic citizenship, legal citizenship, ethical citizenship, philanthropic citizenship and job pursuit intention.

Sampling method in this research is non-probability with purposive technique. Non-probability sampling means that every member in population has different probability to be chosen while purposive technique means respondents are chosen because meet the criteria set by researcher (Cooper, 2011). This research involves final year student of Faculty of Economics and Business Universitas Indonesia. Data analysis uses simple regression with help from SPSS (Statistical Package for the Social Science) 20.0 software.

Regression analysis is conducted in 2 steps. The first step is designed to examine 4 dimensions of CSR into job pursuit intention to Tobacco Company. This step aims to find out strength and effect of economic citizenship, legal citizenship, ethical 
citizenship, and philanthropic citizenship as independent variables into job pusuit intention as dependent variable. The second step aims to examine relationship between CSR and job pursuit intention to Tobbaco Company by inserted socio-environmental consciousness as moderating variable. This step is conducted by regressing independent variable, moderating variable, and new variable which resulted by multiplied CSR and socio-environment consciousness with dependent variable. Moderating variable is significant as moderator if siginfication value of new variable (variable of multiplication between CSR and Socioenvironment consciousness) equals as or less than 0.05

\section{RESULTS AND DISCUSSION}

Total respondents who participate are 203 students. Majority of respondents are female accounted $62.5 \%$ and male accounted $37.5 \%$. In this research female dominated because in population total of female students are bigger than male students; $58.7 \%$ for female and $41.43 \%$ for male. The majority of respondents are 21 years old or $60.2 \%$, and as many as $61.1 \%$ respondents majoring in management, $25.9 \%$ majoring in accounting, and $13 \%$ majoring in economics.

Table 1: Job Choice Factors Consideration

\begin{tabular}{lc}
\hline \multicolumn{1}{c}{ Factors } & Frequency \\
\hline Salary and Benefit & 185 \\
Promotion Opportunity & 60 \\
Image and familiarity of company & 54 \\
Opportunity of self development & 131 \\
HR Practices of company & 16 \\
Company's concern on environment & 26 \\
Location & 60 \\
Working Hours & 53 \\
Type of Job & 99 \\
Company's CSR Program & 8 \\
\hline
\end{tabular}

Before starting to ask questions to measure CSR, job pursuit intention, and socio-consciousness, respondents were asked on what factors they will consider to choose a place to work. Respondents answer to this question is summarized in the table 1. Respondents mentioned salary and benefit as factor they consider when choosing for a job. It is mentioned by 185 persons of total respondents, followed by opportunity of self development mentioned by 131 persons, and type of job mentioned by 99 persons. This result is not surprising since Lynne and Therese (2014) stated that fresh graduates financially have burden to pay out educational cost spent when pursuing degree and after graduated they are forced to competitive labor market where they need to find a job which can compensate their initial investment. Thus, financial rewards are the main factor to consider when choosing a place to work right after they graduated from university.

To test hypotheses 1-4, simple regression analysis was conducted. This step tries to relate 4 dimensions of CSR (economic citizenship, legal citizenship, ethical citizenship, and philanthropic citizenship, IV) as separated independent variables to job pursuit intention to a Tobacco Company as dependent variable (DV). Thus it will produce 4 regression equations. This test aims to examine factors of CSR which have the biggest effect on job pursuit intention by observing value of $R$ square in every equation. $\mathrm{R}$ square indicates percentage value of dependent variable can be explained by its independent variable in the equation. This test also aims to see the direction of relationship whether positive or negative by examining beta coefficient in every equation.

To test hypothesis 5, socio-environment consciousness was added as moderating variable into 4 regression equations. Every equation consists of independent variable (dimensions of CSR, IV), moderating variable (socio-environment consciousness, MV), and new variable which is resulted from multiplication of independent and moderating variables (IV, MV). These 3 variables are related to dependent variable (job pursuit intention to a Tobacco Company, DV). To conclude that moderating variable is significant to strengthen or weaken relationship between independent and dependent variables, it is seen by observing significant values of MV and IV$\mathrm{MV}$ in equation. If it is bigger than 0.05 , it means there is no effect of moderation variable into relationship between independent and dependent variables. The hypothese testing result is summarized in table 2 . 
All 4 dimensions of CSR are positively affected job pursuit intention students to Tobbaco Company. This result is in accordance with previous researches which stated that CSR activities will be positively impacted intention of people to apply job to a company which perceived as socially responsible. However, if we carefully examine the result, it reveals that ethical citizenship as dimension of CSR which can explain job pursuit intention better compare to others dimensions. It indicates from the R square value in the equation which scored the biggest among others (0.299) with beta coefficient 0.481 . Ethical citizenship is public demand to company that in conducting business activity, company must be aware to local norms and respecting local wisdom. Company should not behave unethically in running business operation which will harm public acceptance and trust. If company is labeled as unethical, it will judged by people as socially irresponsible company and will decrease a likelihood people to get a job in a company. This result indicates that even though Tobacco Company is controversial, but it can maintain its positive image by ensuring that it operates ethically. Company should pay more attention to local norms and custom, respecting community, and implementing good corporate governance as one of tool to ensure that company behaves ethically. After ethical citizenship, economic citizenship is followed as a CSR dimension which could explain job pursuit intention with $\mathrm{R}$ squre 0.201 and beta coefficient 0.451 . It means that when choosing a place to work, students will perceive whether a company is socially responsible or not in term of economics treatment. If the company is considered as an organization which implements justice and fairness in treating their employees, the likelihood of people to apply for job in the company will increase. Thus, the company must enact justice as a principal in formulating compensation strategy. Because if company is perceived as fair, it will shape mindset of people that the company is socially responsible.

Table 2: Hypothese Testing Result

\begin{tabular}{|c|c|c|c|c|c|c|}
\hline & Hypotheses & \multicolumn{2}{|c|}{ Sig. } & Beta & R Square & Results \\
\hline H1 & $\begin{array}{l}\text { Economic citizenship positively affects job } \\
\text { pursuit intention }\end{array}$ & \multicolumn{2}{|c|}{.000} & 0.451 & .201 & Accepted \\
\hline $\mathrm{H} 2$ & $\begin{array}{l}\text { Legal citizenship positively affects job } \\
\text { pursuit intention }\end{array}$ & \multicolumn{2}{|c|}{.000} & 0.334 & .111 & Accepted \\
\hline H3 & $\begin{array}{l}\text { Ethical citizenship positively affects job } \\
\text { pursuit intention }\end{array}$ & \multicolumn{2}{|c|}{.000} & 0.481 & .229 & Accepted \\
\hline \multirow[t]{2}{*}{$\mathrm{H} 4$} & $\begin{array}{l}\text { Philanthropic citizenship positively affects } \\
\text { job pursuit intention }\end{array}$ & \multicolumn{2}{|c|}{.000} & 0.403 & .162 & Accepted \\
\hline & Hypotheses & $\begin{array}{l}\text { Sig1 } \\
\text { (IV) }\end{array}$ & $\begin{array}{l}\text { Sig2 } \\
\text { (MV) }\end{array}$ & $\begin{array}{l}\text { Sig3 } \\
\text { (IV, } \\
\text { MV) }\end{array}$ & R Square & Result \\
\hline $\mathrm{H} 5 \mathrm{a}$ & $\begin{array}{l}\text { Socio-environmental consciousness } \\
\text { moderates the effect of economic citizenship } \\
\text { towards job pursuit intention. }\end{array}$ & .000 & .317 & .144 & .230 & Rejected \\
\hline $\mathrm{H} 5 \mathrm{~b}$ & $\begin{array}{l}\text { Socio-environmental consciousness } \\
\text { moderates the effect of legal citizenship } \\
\text { towardsjob pursuit intention. }\end{array}$ & .000 & .178 & .059 & .154 & Rejected \\
\hline $\mathrm{H} 5 \mathrm{c}$ & $\begin{array}{l}\text { Socio-environmental consciousness } \\
\text { moderates the effect of ethical citizenship } \\
\text { towards job pursuit intention. }\end{array}$ & .000 & .490 & .303 & .240 & Rejected \\
\hline H5d & $\begin{array}{l}\text { Socio-environmental consciousness } \\
\text { moderates the effect of philanthropic } \\
\text { citizenship towardsjob pursuit intention. }\end{array}$ & .000 & .357 & .115 & .197 & Rejected \\
\hline & & & & & & \\
\hline
\end{tabular}


However, in this research socioenvironmental consciousness does not moderate relationship between CSR and job pursuit intention. It means that socioenvironment consciousness neither strengthens nor weakens effect of CSR into job pursuit intention. It will ease Tobacco Company in formulating strategy to build positive image through CSR action to increase job pursuit intention. To increase job pursuit intention, company can ignore individual difference about awareness level to social issues. To attract qualified candidates, company just need to focus on how to shape positive mindset in public through CSR activities especially in ensuring that company behaves ethically in doing business. Positive image as an ethical company will give positive impact to company including Tobacco Company even though cigarette as products of Tobbaco Company is controversial in public because it is believed can cause health problems. If Tobacco Company can win public hearth through conducting CSR actions which widely accepted by people, it will compensate the controversial side of cigarette and still considered as socially responsible company.

Positive image will leverage intention of people to join and get a job from Tobacco Company. Based on the finding, job pursuit intention is not affected by subjective factor of a person such as level of morality but simply affected by objective factor of the company. If the company is perceived as social responsible, level morality of people will not strengthen nor weaken the likelihood to apply, but if the company is perceived as socially irresponsible it will directly affect the likelihood of people to apply for a job in negative way. Thus to be competitive by winning war of talents, Tobacco Company needs to pool as many qualified human resource as possible by increasing job pursuit intention of job seekers to apply. To ensure high level of job intention, company needs to shape its positive image in the eye of public by implementing good CSR activities.

\section{CONCLUSION AND LIMITATION}

This research concludes that company needs to develop the employees' job pursuit intention to fulfill the needs of qualified human resources in order to increase the company's performance. The higher employee's job pursuit intention gives the company bigger opportunity to get the qualified human resources.

One of the strategies than can be implemented by the company in order to increase the job pursuit intention is to improve the previous CSR activities that have been carried out by the company. CSR activities comprise 4 dimentions: economic citizenship, legal citizenship, ethical citizenship and philanthropic citizenship. There are some programs that can be made including develop a positive image in people mindset, more respect to regulation and law which govern the business activities such as advertisement regulation, procurement for smoking area, responsible for women, maternity and children protection from the danger of cigarettes and perform the CSR activities that can improve social wellfare in general. This is because ethical citizenship has the greatest influence on job pursuit intention.

This research also shows that socioenvironmental consciousness as a variable does not moderate the influence of the four dimention of CSR on the individual's intention to apply to the company. This indicates that the respondent of this research, which is the final year students from Faculty of Economy and Business Universitas Indonesia, does not involve the socio-environmental consciousness factor in choosing and determining the jobs, but they simply evaluate the company's CSR activities objectively regardless their level of socio-environment consciousness.

The limitation of this research is from the sample frame; in this case is the final year students from only one faculty which is Faculty of Economy and Business Universitas Indonesia. This causes the result can not be generalized to all job seekers. The questions in the questionnaire related to some variables like economic citizenship, legal citizenship, ethical citizenship and philanthropic citizenship are also mostly evaluated subjectively towards the company's CSR activities. Respondent does not know the company's CSR activities accurately so that they filled the questionnaire based on their own perceptions. 


\section{REFERENCES}

Adetunji, O. J., Ogbonna, I. G. (2013). Corporate social responsibility as a recruitment strategy by organization. International Review of Manajemen and Business Research, 2 (2), 313317.

Aiman-Smith, L., Bauer, T.N., \& Cable, D.M. (2001). Are you attracted? Do you intend to pursue? A recruiting policy-capturing study. Journal of Business and Psychology, 16 (2), 219-237.

Bauer, T.N., \& Aiman-Smith, L. (1996). Green career choices: the influence of ecological stance on recruiting. Journal of Business and Psychology, 10 (4), 445-458.

Chang, C. \& Chen, Y. (2012). The determinant of green intellectual capital. Management Decision, 50 (1), 74-94.

Chapman, D.S., Uggerslev, K.L., Carroll, S.A., Piasentin, K. A., \& Jones, D. A. (2005). Applicant attraction to organizations and job choice: a meta-analytic review of the correlates of recruiting outcomes. Journal of Applied Psychology, 90 (5), 928-944.

Cooley, C.H. (1907). Social consciousness. American Journal of Sociology, 12 (5), 675-694.

Cooper, D. R., \& Schindler, P. S. (2011). Business research methods $\left(12^{\text {th }}\right.$ ed.). United States of America: The McGraw-Hill Companies, Inc.

Djarum. (n.d.). Februari 3, 2016. http://djarum.com/terms-conditions/

Kajian Singkat Potensi Dampak Ekonomi Industri Rokok di Indonesia. (n.d.). Januari 6, 2016. http://www.bentoelgroup.com/group/sites/bat a5eeyp.nsf/vwPagesWebLive/ DO9T5K5L/\$FILE/medMDA5EGZ2.pdf?openelement

Kementerian Kesehatan Republik Indonesia. (2015). Stop kanker. Januari 6, 2016. http://www. depkes.go.id/resources/download/pusdatin/infodatin/infodatin-kanker.pdf

Leveson, L., \& Joiner, T. A. (2014). Exploring corporate social responsibility values of millennial job-seeking students. Education + Training, 56 (1), 21-34.

Lin, C., Lyau, N., Tsai, Y., Chen, W., \& Chiu, C. (2010). Modeling corporate citizenship and its relationship with organizational citizenship behaviors. Journal of Business Ethics, Vol. 95, 357-372.

Mandina, S.P., Maravire, C.V., \& Masere, V. (2014). Effectivensess of corporate social responsibility in enhanching company image. Journal of Applied Business and Economics, $16(3), 152-167$.

Nuryanti, S., \& Rachmat, M. (2009). Dinamika agribisnis tembakan dan implikasinya bagi Indonesia. Forum Penelitian Agro Ekonomi, 27 (2), 73-91.

Olsen, K.L., Cudmore, A., \& Hill, R.P. (2006). The impact of perceived corporate social responsibility on consumer behavior. Journal of Business Research, Vol. 59, 46-53.

Perilaku Merokok Masyarakat Indonesia. (n.d.). Januari 6, 2016. https://www.google. $\underline{\text { co.id/?gws }}$ 